\title{
ENTREPRENEURIAL OPPORTUNITIES IN INDONESIA TO INITIATE BUSINESS THROUGH IMPORTER COMMUNITIES
}

\author{
Harefan Arief ${ }^{1 *}$, Eko Tama Putra Saratian ${ }^{1}$ \\ Faculty of Economics and Business, Mercu Buana University \\ *harefan.arief@mercubuana.ac.id
}

\begin{abstract}
This research is to analize the entrepreneur group esspecially small medium enterprise in seeking funding from many people (crowdfunding) in way to find capital goods which purchased from abroad then to be sold to the domestic market. Analyzing how they search for goods of capital through e-commerce and through visits to exhibitions abroad, especially to China. This phenomenon born along with the emergence of start up that created a media that connecting the customer and manufacturing companies. This business models should meet in order to support sustainable innovations. Study case of this research is one of the community importers. This study uses a qualitative approach with literature review method. As a result, this research is expected to motivate entrepreneurial interest and the ability to create businesses that ultimately have an impact on the economic and social fields.
\end{abstract}

Keywords: Crowdfunding, entrepreneur, import, suistainable innovations

\section{INTRODUCTION}

According to data The Ministry of Menpower (Menaker) in 2017 the number of growth entrepreneur in Indonesia rose 3.4\% from the previous year at 3.1\%. This growth exceeds International Standard which is $2 \%$. This growth figures is still infirior to other ASEAN neighboring countries such as Malaysia which has grown 5\%, Thailand has grown $4 \%$ and Singapore has grown to $7 \%$. The Chinese state of entrepreneurial growth has reached $10 \%$ and Japan has reached $11 \%$.

By looking at the comparation of the growth achievement of other countries, it is expected Indonesia to be more competitive. To be able to achieve increased entrepreneurial growth, the government should collaborate with large companies to provide entrepreneurship education and training.

Community empowerment by conducting entrpreneurship training and development aimed for Micro, Small and Medium Entreprises. Besides that, there is also the need for training on how to get access to funding in creatig a new company. As known, one of the obstacles to the creation of new entrepreneur is funding. In other side the cultural minset of the Indonesians where the measures of success is graduatig from school or college then getting a job.

In the past few years, along with the development of shophisticated information technology through the internet and emerging social media it has greatly contributed to the creation of new entrepreneurs. Many people begin to use the internet and social media as their business platform. Even through social media they making business groups or business communities have been formed. Where as the formation of the community initially was aimed for marketing network, looking for raw material products until finally forming a funding network.

In order to find the raw material if the material limited or not produce in the country they start to find from abroad. They together funding themselves, using Internet they communicate to the vendor outside the country such as China, Vietnam etc.

This study aims to analyze entrepreneurial groups, especially middle and small entrepreneurs in seeking funding from many people (crowdfunding) to bring capital goods in whereas purchaced form abroad which then sold to the domestic market. Analizing how they look for capital goods or raw material through e-commerce and through visit the exhibition abroad, especially to China.

This phenomenon was born along with the emergence of the start-up created media that connects the customer and manufacture. This business model must support sustainable innovation. This 
researh examines one business community of importers. This study uses a qualitative approach with literature review methods. As a result, this research is expected to motivate entrepreneurial interest and ability to create businesses that ultimately have an impact on the economic and social fields.

\section{THEORITICAL FRAMEWORK}

The Global entrepreneurship monitor (GEM), reports that entrepreneurship is now center stage in the public policy arena of most countries. As the increasing social, environmental and economics challenges facing humanity now adays, many people believes that's business have an important role to play in transforming society in the future. Entreprenuer are considered to have particular role in inovation and bringing about societal change, traditionaly from perspective of a macro economic (Wenneker et al, 2012).

Entrepreneurs are people who have ability to see and to evaluate business opportunities, collect the resources needed to take appropriate action, utilize and have the nature, character and willingness to bring innovative ideas into reality and creatively in order to achieve success or to increase the revenue. Essentially an entrepreneur is people who have an entrepreneurial character and apply the entrepreneurial nature of life. In other definition, entrepreneurs are people who have character creativity and innovative high spirit in life. From some of concepts in the show as if entrepreunership are synonymous with the entrepreunerial skills in business (Constantinescu, 2008).

Where as, in reality, entrepreneurship is not always synonymous with entreprenurial character because an entrepreneurial character may also be owned by a non entrepreneur. Entreprenurial covers all aspect of work, both the private and government employees. (Seetanah, 2009) the linked between economic education and entrepreneurs are those who make efforts in creative and innovative way to economic growth.

Entrepreunerial has established its position as the strongest economic power above last decade. Entrepreneurship, therefore, has been seen as a 'panacea for unemployment problem', in the other words, entrepreneurship is considered as a solution for unemployment rate (Ahmad \& Xavier, 2012).

The concept of entrepreneurship and entrepreneurial character is still growing. Entrepreneurship is attitude, spirit and ability to create something new that is very valuable and useful for themselves and others. (Duanmu and Yilmas, 2013) found entrepreneurship is an attitude and spirit that is always active or creative power, and unpretentious work and effort in order to increase revenue in their business activities. That entrepreneurship attracts many parties to understand it is to contribute entrepreneurial attitudes acquired various parties to perform actions related to entrepreneurship. (Timmon and Stephen, 2017) make the grouping needed for entrepreneurial action in six issues: (1) Commitment and determination, (2) Leadership, (3) Obsession to the opportunity, (4) tolerance toward risks, ambiquity and uncertainty, (5) Creativity, and (6) Motivation for achievement.

The inclusion of sustainability into entrepreneurial actitivity makes this in the entreprenurial literature, ensuring that remained an additional aspect rather than an integrative aspect of entrepreneurship. Many corporate sustainability researches have focused on the economic and environmental dimension of suistainability. One of research that has explored sustainability issues holistically is Klapper and Upham (2015). They examine how the daily practises of small and micro enterprises simultaneously achieve various dimensions of sustainability. They created a model connection micro firm entrepreneurship and value creation to the economic, social and environmental aspects of sustainable development.

Schumpeter's theory that capitalism develops entrepreneurship as a driving force has recently attracted more attention (Aghion and Akcigit, 2015). Schumpeterian model presents entrpreneurship and the company as the central of economic growth. Entrepreneurship in managed economics has a negative impact of economic growth but entrpreneurial economy is main driving force of growth (Armington, 2004). The failure of an enterprise in managed economy is considered negatively and perceived as wasting of social capital. On the other side, failure in the entrepreneurial economy is considered as results from experimental activities and social learning. There must be an entrepreneurial innovator for encourage innovation, and this is the key. So, it needs to be made research on entrepreneurship is more academically and politicaly. Innovation in the transition period is basically dangerous and must be done with failure. Therefore, it is not important to support a successful project, rather to persue experimental innovation (Kim, 2018). 
Also, there is qualitative research on entrepreneurial research. (Joseph, Wayn, 2008) they focused on entrepreneur in the maritime field pilot industry that want to make changes and illustrates how professional associations that work with and through the government can prevent individual members from becoming innovative. (Shin, 2017) learned to examine organizational processes turn into new entrepreneurship like a company spinoff or intrapreneurship. (Santandreu-Mascarell, Garzon and Knorr, 2013) revealed one way entrepreneurs contribute to economic development is through innovation that involves the growth of new products, new processes, new supply sources, new markets exploitation, and the development of a new ways to organize business; thus innovativeness can be presumably associated with intrepreneurial intention.

(Harris and Gibson, 2008) reported that students with family business experience had developed strong entrepreneurial attitudues. Family have an impact on an individual's entrepreneurial intentions in terms of role modelling perspective and considered parents to play an important role in entrepreneurial career of their childrens. (Franke and Luthje, 2004) claimed that environmental factors is facilitating entrepreunerial activities then affecting the alleged benefit percentage of new compamy; therefor may have an important role in forming entrepreneurial intentions among students.

Entrepreneurship barrier includes difficulties in obtaining institutional support for inspiring entrepreneurs, receiving family support, securing financing from lenders, building a relationship with suppliers and a solid cutomer base (Shinnar, Giacomin \& Jansen, 2012). When potential entrepreneurs realize a hostile environment for business founders such as credit conditions as being to restrictive, they are less likely to become entrepreuner irrespective of their attitude toward self employment. The legal framework, financing and access to capital is a subject of intrest for entrepreneurs. The highest rank determinants of enterepreneurial activity are access to finance and access ro knowledge or training.

The Entrepreneurship is a process of applying creativity and innovationess in gathering resources to find opportunities and improvements in solving problems and finding opportunities to improve life. Entrepreneurship is an attempt to create added value by way of entrepreneurship that arise when an individual dared to combine resources in ways new and different for developing business and new ideas. The Entrepreneurial process includes the use of all functions, activities and action related to acqusition opportunities and the creation of business organization to win the competition (Sigfusson and harris, 2013).

\section{Crowdfunding}

Crowdfunding is defined practice of funding a project or venture by raising some amounts of money from many people, now adays crowdfunding more developed via internet technology. Crowdfunding is a unique category of funds raising which building inspiration such as micro finance and crowd sourcing and now more growing through the Internet.

In recent years, particularly since 2010 , equity based financing though online crowdfunding has undergone rapid development (Tomczak and Brem, 2013). The crowdfunding models, investors are faces eith hogh uncertainty about result project and the reliability and credibility of the project initiator (Moss et al, 2014) Previous research has shown that investors use information a lot provided by project initiator to facilitate investment decision.

Various research that focus on the information provided by project initiators found the readiness of entrepreneurs for example through quality information material provide and regular information updates positively influence investor financing decision in crowdfunding (Mollick, 2014; Ward and Ramachandran, 2010).

Reputable investors invest in some projects and established a crowdfunding platform and encourage the project identified as a positive indicator for successful funding (Belle flickme et al., 2014; Heminway, 2013). The main barriers for the funders is distrust of the the way entrpreneurs use the funds, which means that they worry that the entrepreneur will not fulfill the objective of the project and will only take the money for themselves (Gerber \& Hui, 2013).

Crowdfunding leverages the easy access of a large network of people through internet especially social media and crowdfunding websites to bring investors and entrepreneurs, and has the potential to increase entrepreneurship by expanding group of investor. (Geda, David; Nilsson, Billy et al, 2016) define seven different crowd funding model which are: (1) Donation, funding a project without expectation of return (free of charge). (2) Reward is funding a project and gaining a rewards that is not 
the actual product and service. (3) Sponsorship is funding a project and in return for publicly visible connection to the project. (4) Pre-order is funding a project by pre-ordering the actual product or service. (5) Lending with interest is funding a project by lending money to the entrepreneur in return for interest. (6) Lending without interest is funding a project by lending money to the entrepreneur in without interest. (7) The Material which means funding a project by buying equity in the firms.

The key factors in fundraising to success are other fieds of studies research (Belleflamme et al., 2014) found that non profit venture initiatives tend to be more successful in fundraising. Project that aim to produce real products tend to be more seccessful than service-oriented project. (Zheng et al., 2014) found that entrepreneurial social capital, social network, obligations to finance other entrepreneurs, and sharing the meaning of crowdfunding project between employers and sponsors are key factors in successful of fundraising in China and the United States.

Another research found that entrepreneur use social networking tools to promote success rate using Twitter and Facebook that entrepreneurs use social networking tools to promote success rate of crowd funding using Twitter and Facebook (Bechter et al., 2011; Mollick, 2014). The entrepreneur activeness in crowdfunding project management is positively related fund raising performance (Balboni et al., 2014). Although crowd investors have some common characteristics such as utilizing the internet, enjoying participation in modern behavior are interested in the use of interctive tools such as social media and expect financial or non-financial returns, crowd investor motives depend on certain crowdfunding models and different information needs (Cholakova and Ccclarysee, 2014; Gerber et al., 2012; Ordanini et., al 2011) .

\section{Innovations}

Innovation related to perceiving and action on business activities in a new and unique way. Innovation refers to the ability of entrepreneurs to produce solutions in new situations which is achieved through training and experience (Littunen, 2000). Innovations in the transition period are basicaly dangerous and must be done with failure. Therefore, it is not important to support succesful project, but more to pursue experimental innovation (Kim, 2018). However, experimental innovation comes from entrepreneurship. There must be an entrepreneurial innovator to drive innovation and these are the key.

The entrepreneurship is the center of the entrepreneurial economy. The entrepreneurship should become active at the age of digital transition. (Samyukta B, et al, 2014) found important differences between the fields. Science and technology studies cumulated trajectory that develops in a more or less linear fashion overtime. Innovation study has diverted attention from main trajectory from macro economic issue to business oriented. Innovation is an important component of entrepreneurship; Howevers, the frequent use of entrepreneurial proxies that do not consider innovation motivates to propose and develop innovative entrepreneurial indicators that are useful for the regions, districts, states and the metropolitan area as well.

Resources constrains are hallmark of entrepreneurship and so entrepreneurial traits strategy is very much influenced by few resources with which entrepreneurs must begin (Hallen and elsenhardt, 2012). Therefore, entrepreneurs should find ways to deal with the lack of resources early on through several strategies including seeking partnership to obtain financial capital (Katila, et. al, 2008). Trends among sustainable innovation with regard to their forms and more importantly the impact both externally and internally, comparing Environtmental innovations and Social innovations. (Abbasa and Wassem, 2017). Environtmental innovation is tended to find a new way of using existing product more than social innovations did but to a lesser extent than offering new product or improving a production process. Social innovations, however tended to offer new services or found new uses for business associated with them more so than environtmental innovations.

The relationships between innovations to individual entrepreneur and collective entrepreneurs are contributed in small business. Some factors that contribute to collective entrepreneurship are also found to contribute to individual entrepreneurship. While factors that are often asociated with individual entrepreneurship are found to have negative impact on collective entrepreneurship. For example communication among members of a small business, which is founds to directly positive contribute to collective entrepreneurship also contribute to individual entrpreneurship. In contrast, the centralized decision making, which is founds to have a negative impact on innovations. (Yan, Jun, Yan, Li, 2016). 


\section{METHOD}

We use some analytical descriptive and the literature review, grounded theory research cunducted to find a theory or to strengthen existing theories by reviewing basic principles and rules existance. Further basic conclusion are made which form the basic pronciples of a theory (Strauss and Corbin, 1996) and inductive research design and move from specific observation to more general view of understanding. How entrepreneurial oppurtunities of crowfunding to initiates business in importer group community. We collect data by joinning 3 importer groups, interviews participants, investors.

This enabled us to trangulate our findings and to access whether our explanations were same across all participants or whether there were differences between groups interviewed (Denzim, 1978). This method allows us to make an understanding the empirical data and to explain, to interpet oppurtunity (Glasser and Strauss, 1966).

In gather data we joined 3 goups importers, joining their project, interview participants and investors. We perform 3 Project of crowdfunding project of each group importer, 40 interviewes with investors in each group, 20 male and 20 female which range age 18-45. Furthermore, our interview partners differed in their academic and professional education, employment status and motivation motive.

\section{RESULT AND DISCUSSION}

The Import business is certainly becoming the type of business that is most intrested way for the new entrepreneur when starting their business. The main problem is how to get fund and capital to establish new business. Nowadays there is a phenomenon in Indonesia where is people create collectives entrepreurship in form business communities, together they recruit member and train them to join the business communities then doing business together. In other word this model of business will be very useful option in motivate people to be a new entrepreneurs.

This research focused on phenomenon in business communities bring in many products from abroad especially from China or we can use terminology Importer wholesale. Defining Import, the Import is bringing in goods or commodities form other country for use, sale or processing. Through social media they published themselves as a business community that offer various projects together, they recruit member who have intend to be entrepreneur. They intense perform seminar and training across the country. This is a creative way in recruiting a new member that eager and have passion and this is opportunity becoming new entrepreneur through this method they can attract new entrepreneurs and to those who have intention to be entrepreneur and together they seek fund and capital or to seek innovative goods or material which to develop into new product which have value added.

Participant who join and took part in the seminar and workshop also varied. There were come from many backgrounds such as college student, bussiness people who had just started their own business, professional workers or even household. They were guided on how to do import and selling the product with multiple benefit and profit.

The import business is importing product which are very profitable. Espescially the imported product is a much needed product. But the way to import the product is still much difficult. The most imported product majority product from china. Although products from china considerated to be poor of quality. But in reality that occurs in the market is the products from china are more easily absorbed by the market because the price is cheap and much more affordable. So this condition is really catching by the professional business people in creating new model business.

\section{Crowdfunding mechanisme in importer business communities}

In order to gather fund and to find material from abroad here are several steps that use by Business communities: (1) every member can submit subject plan. (2) The Project woth running is determined by all members. (3) The leader project is the initiator project. (4) The project Initiator looking for materials needed by searching through online marketplace website. (5) Together make a calculation how much the funds is needed to import material. (6) The project initiator offer crowdfunding in the communities. (7) The Project initiator calls and communicate with the suppliers 
abroad. (8) The project initiator and team should find many suppliers in order to find a competitive price. (9) After the material supplier is obtained, the initiator and team will then begin to discuss the cheapest way to import it to Indonesia. (10) Raising Funds. The inisiator project collects the fund. The investors who joint the project should be confined so profit sharing becomes large. (11) All funder will get benefit according to proportion they're invested.

\section{Types of Project}

There are two type of project:

Project Import Goods for Sale purposes, This project is bring in many kinds of goods or material like toys, home appliance, special electronic device, safety stuff, fashion accessories, Mobilephone accessories etc. The imported goods are directly distributed to the funder for sale in the domestic market or together market it in marketplace using any platform.

Project Import Material for Processing, this project purposes bring in raw material or industrial machinary. The researcher participated with the business communities in order bringing in machinary such as industrial washing machine, Industrial ice maker, Mobilephone spareparts, automotive spareparts. Also participat import the raw material for plastic industries (plastics pellets). Special for this kind of projet the materials are not sale directly but for other companies which need material supply.

Following this will provide a way to import cheap products from China. (1) visit China Marketplace Website such as Alibaba.com, Bangood.com, Taobao.com and 1688.com. The most popular and famous marketplace website is Alibaba.com this website provides a variety of cheap products from china. There are many entrepreneurs who import Chinese products through Alibaba.com. Therefore as a beginner entrepreneur it is very advised trying import business through Alibaba.com. Before doing import and transaction we need join and create an account in this market place. (2) Choose the suppliers, after successfully create an account on Marketplace the next step is to determine the supplier. It is a must to choose a product that is certainly needed by the community. Also pay attention to the minimum quantity products which is to be purchased. After determining products the next step is choosing supplier. Choose supplier who had good rating it is indicates by gold rating. In addition it is also very important look for supplier in three requirements as follows; Assesed Supplier, Assesed supplier means the supplier has been assessed by Alibaba. Trade Assurance; this kind of supplier is very trusted and considerable because this supplier provides quality, shipment insurance, because many cases of shipment accurs demaged product. Receive payment with paypal or Escrow; Payment using Paypal or Escrow will be more benefit besides easy, if there is a problem will be easier to complain. (3) Try to Negotiate. Negotiation to the supplier is very important sometime for one product we find many differences of prices and condition from many suppliers. There are costs component that need to be consider which are shipping fee and insurance.

\section{The Motive of Import}

Obtaining material, sometimes raw materials in the country are very limited while these raw materials are needed for the continuation of production activities. Obtaining goods and commodities which are not produced in country. Obtaining modern technology, bring in modern equipment in order supporting production. Reexporting, export goods and commodities that were previous imported into a country then sending to another country.

\section{Import Method that use}

In order to import the material there are several method. Usually the method used is the official and Legal. That method is Undername. The undername Import namely activities to bring in goods or commudities from abroad using the name of another company that has legal and has been registered by Customs Authority and has official permission to perform Import. Here, the company only acts as the name provider, while the perpetrator is another company. There is something that needs to be known about the procedures in determining the company to be borrowed for this import activity. 
Before making a shipment transaction, the name borrowing company should confirm to the supplier and shipper in advance about the company to be borrowed, along with its position in the agreement. After the supplier stated there is no problem. Also need to confirm again about the completeness of the shipping document such as invoices, packing list, bill of landing and so on. Finaly, we must also confirm to the undername company about the readiness to carry out import process. If everything is ready, then the process of sending material can also to be done.

After the goods received at the destination ports, the fright forwader will be prepared to take care of all documents for customs cleareance through the Electronic Data Interchange (EDI) system. This system requires the forwarder agent to pay import duties to the bank after making customs notification about the importation to the Custom Office by supporting the documents.

Types of The undername import, which are; (1) Undername QQ system; Bil of landing, packing list, invoice, Form D, E, and AK included in system Undername QQ, (2) Door to Door; prices are offered in detail starting from exworl charge fees, ocean or air freight, local charge fees, undername fees, customs service fees and delivery fees to the destination of the owner of material using undername services, (3) Port to Door or FOB to Door delivery: Pricess offered, starting from the port of the country of origin to the warehouse where the owner or real consignee and the pattern are not much different from the official door to door, the costs will only reduced for trucking, local handling and port cost country origin or according to agreement between buyer and seller. (4) The Local Port, This method is done in stages, the undername party offers a price for flag rental services as well as customs clearance fees clearly and precisely until the goods come out and if there is a fee they will notify their customers.

\section{CONCLUSION}

This research finding concludes that's number factors join a business community.

This Research elaborates this factor as follows: (1) The main factor is limited funding, many people have the intention to be entrepreneur but contrained due to limited funding, (2) Limited information and knowledge about how to look for goods or material and then make that goods or material have value added and suits for sale, (3) Lack information about procedures, (4) Lack of managerial skill, (5) Lack of marketing skill.

The benefit joining in a business importer community; (1) Increasing knowledge about import business; when joining business communities will meet people from various backgrounds and skill, it is valuable opputunity we may learn and get sharing information and their experiences in import business. (2) Joining communities becoming know about legal and procedures in import wold. (3) Increase self esteem in business; joining business importer communities will increase motivation and support from many people in build own business. (4) Expanding network; joining in bussines communities gaining many benefits like opportunity to expand network, having strong relationship and sometime we can build new business. (5) Getting to know of how to find supplier or vendor from abroad.

In opening up the horizon about business it is important for prospective entrepereneurs joining business communities, relationship are investment. Collectiveness Entrepreneurship proves in creating innovation and communication become more effective and harmonious. Ultimately will create suistainablity innovation and business and also will develops networking and supply chain. Establish relationship and find people with similar ways of thinking can provide support to motivate entrepreneurial interest, sustainable innovation and the ability to create businesses that ultimately have an impact on the economic and social fields.

\section{REFERENCES.}

Abaza and Wassem, (2017) Comparing internal and external impacts of sustainable innovations: an exploratory study, The journal of global Entrepreneurship Research, Vol.7 No.1-18.

Al Manun, Abdullah. Fajrah, Siti. Noorshella and Zakaria, (2017) Factors affecting entrepreneurial intention among Malaysian University Student, The journal of developing areas, Vol.51 No.6 
Alexandra, Moritz and Joern, Block, (2015), Investor communication in equity-based crowdfunding: a qualitative-empirical study in Entrepreneurship/Entrepreneurial Finance Journal www.emeraldinsight.com/1755-4179.htm

Belleflamme, P., Lambert, T. and Schwienbacher, A. (2013), "Individual crowdfunding practices", Venture Capital, Vol. 15 No. 4, pp. 313-333.

Belleflamme, P., Lambert, T. and Schwienbacher, A. (2014), "Crowdfunding: tapping the right crowd", Journal of Business Venturing, Vol. 29 No. 5, pp. 585-609. Berkovich, E. (2011), "Search and herding effects in peer-to-peer lending: evidence from prosper.com", Annals of Finance, Vol. 7 No. 3, pp. 389-405.

Cholakova, M. and Clarysse, B. (2014), "Does the possibility to make equity investments in crowdfunding projects crowd out reward-based investments?", Entrepreneurship Theory and Practice, Vol. 39 No. 1.

Duanmu, J-L and G Yilmaz (2013). "Heterogeneous effect of the etnic network on international trade of Thailand, the role of family ties and etnic diversity". International Business review Elsevier 2(1): 126-139.

Franke, N \& Luthje, C. (2004). Entrepreneurial intentions of business students-A benchmarking study. International Journal of Innovation and Technology Management, 1(03), 269-288.

Gerber, E., Hui, J. and Kuo, P. (2012), "Crowdfunding: why people are motivated to post and fund projects on crowdfunding platforms", Proceedings of the International Workshop on Design, Influence, and Social Technologies: Techniques, Impacts and Ethics, available: www.juliehui.org/wp-content/uploads/2013/04/CSCW_Crowdfunding_Final.pdf (accessed 29 December 2014).

Hemer, J., Schneider, U., Dornbusch, F. and Frey, S. (2011), Crowdfunding und andere Formen informeller Mikrofnanzierung in der Projekt-und Innovationsfnanzierung, FraunhoferVerlag,Stuttgart.

Heminway, J. (2013), "The new intermediary on the block: funding portals under the Crowdfund act", UC Davis Business Law Journal, Vol. 13 No. 2, pp. 177-205.

Mollick, E. (2014), "The dynamics of crowdfunding: an exploratory study", Journal of Business Venturing, Vol. 29 No. 1, pp. 1-16.

Mollick, E. and Nanda, R. (2014), "Wisdom or madness? Comparing crowds with expert evaluation in funding the arts", Harvard Business School Working Paper No. 14-116, available: http://papers.ssrn.com/sol3/papers.cfm?abstract_id2443114 (accessed 12 June 2014).

Santandreu-Mascarell, C., Garzon, D., \& Knorr, H. (2013). Entrepreneurial and innovative competences, are they the same? Management Decision, 51(5), 1084-1095.

Seetanah, B (2009), The economic importance of economics: evidence from africa using dynamic panel data analysis. Journal applied economic. UCEMA, 12 (1) 1-9.

Sigfusson,T.and Harris, S (2013). "Domestic market context and international entreprenuuers'relations portfolio". International Business Review. Elsevier, 22(1): 243-258.

Timmon, J and Stephen, S, (2007). "New Venture Creation, Entrepreneurship for $21^{\text {st }}$ century, New york: Mc Graw Hill. 
Tomczak, A., and Brem, A. (2013). A Conceptualized Investment Model of Crowdfunding. Venture Capital, 15(4): 335-359

Yan, Jun \& Yan, Li (2016). Individual Entrepreneurship, collective entrepreneurship and innovation in small business: an empirical study. International Entrepreneurship and Management Journal, Vol 12: 1053-1077. 